\title{
Social Partnership in the System of Regulation of Labor Relations
}

\author{
Asel Rashidova ${ }^{1}{ }^{*}$ Shadrina Ekaterina ${ }^{1}$, Khasan Radjabov $^{2}$, Angela Manatova $^{2}$, \\ Larisa Shabanova ${ }^{2}$
}

\author{
${ }^{1}$ Herzen State Pedagogical University of Russia, Russia \\ ${ }^{2}$ Dagestan State University, Russia \\ *Email: aselisa@mail.ru
}

\begin{abstract}
The article reveals the specifics of social partnership and its place in the modern legal regulation system of workers' labor in the Russian Federation. Social partnership is a set of ways in which employees and their representatives, employers and their representatives, state authorities, and local self-government bodies coordinate employees and employers' interests in regulating labor and directly associated relations. The specifics of the formation of social partnership relations at the present stage is their formation in the conditions of refusal from the centralisation of labor relations regulation. In market conditions, when state regulation of social and labor relations is minimised, it is only through a social partnership between the employer and the employee that it is possible to negotiate and achieve high economic results on mutually beneficial terms. The system of social and labor relations is vital for society, as it sets economic development direction.
\end{abstract}

Keywords: Social partnership, Sphere of labor, Labor relations, Interaction of the parties of labor relations, Labor conflicts.

\section{INTRODUCTION}

In current conditions, the prevailing method of regulating wage labor relations is the method of reaching an agreement between labor and capital, called "social partnership".

Social partnership in a broad sense is a jointly distributed activity of social elements - representatives of various social groups, the result of which is positive effects accepted by all participants in this activity. Simultaneously, these activities can be carried out permanently and situationally, through specially planned actions within the social partnership framework.

The presence of both opposite and common interests leads, on the one hand, conflict relations between workers and employer, on the other, the need for agreement on the "social world", developing mechanisms to provide a combination of industrial and social aspects of the organisation (employer). Such mechanisms are commonly referred to as "social dialogue" or "social partnership" (a term adopted in the Russian Federation).

The development of social and labor relations in the Russian Federation is associated with solving the problem of coordinating the economic and social interests of participants in the labor process to prevent contradictions between employees and employers, which often lead to labor protests, causing significant economic, financial, temporary and moral losses, reducing the competitiveness of enterprises and disrupting their livelihoods [1].

The term social and labor partnership itself reveals the system of relations between the employer, authorities and employees' representatives. While these relationships are regulated by labor legislation: "Social partnership in the labor sphere - system of relations between employees (employee representatives), employers (representatives of employers), state authorities, local authorities, directed on ensuring coordination of interests of employees and 
employers on issues of labor relations and other directly related relations" [2].

The Institute of social partnership research's relevance is also connected with new fundamental processes characteristic of the sphere of work. According to the report "The Future of Jobs" prepared by experts of the World Economic Forum in 2018, along with the ongoing formation of the digital economy, it is now possible to state the implementation of the so-called fourth industrial revolution, which is characterised by the development and mass introduction of artificial intelligence, automation, and robotics into production [3].

\section{RESEARCH METHODOLOGY}

In the preparation of the article, we used, first of all, comparative-legal, historical, system methods, as well as the formal-logical method.

The idea of social partnership was borrowed from the experience of Western countries: Germany, Austria, Sweden, Switzerland, etc., where the model of the capitalist social market economy was implemented, a high degree of social protection of workers was achieved, there are strong and authoritative trade unions, and institutions of labor democracy were established at enterprises [4].

Many scientists have studied this issue. The analysis of the interaction of the state, business and civil society, the trends in modern states' development are given in V. Guttman works, who considered industrial policy as "the sum of all measures, both direct and indirect, to influence the enterprises of the industrial sector" [5].

A deeper understanding of tripartite social partnership was influenced by the scientific works of $\mathbf{J}$. Nelson and S. Zadek, who defined it as "people and organisations from a certain combination of the public, business and civil society who participate in voluntary, mutually beneficial, useful, innovative relationships in solving common social goals by combining their resources and competencies" [6], as well as domestic researchers S.P. Peregudov, G.P. Zinchenko, I.I. Rogov, for whom tripartism is "a mechanism for regulating labor and related socio-economic relations based on social dialogue and cooperation of "strong" social forces and their associations (trade unions, associations, unions, etc.), as well as interested persons (consultants, experts, etc.)" [7] and "if the super-task of the old tripartism was to mitigate socio-class contradictions and achieve social partnership between business and wage earners, the new tripartism concentrates on solving other socially significant tasks, mainly on the system of social services and social infrastructure in the broadest sense of the word" [8].
The most common view is that the prerequisites for the emergence of a system of social partnership originated at the end of the 19th century when trade unions and business unions began to emerge; in the first decades of the next century, the social partnership developed intensively, which, to a large extent, was facilitated by the formation in 1919 of International Labor Organisation (ILO). As the trade union movement grew stronger, employers' associations began to emerge, but no one talked about the social partnership at that time. Since the beginning of the 20th century, it took about half a century for such a concept as "social partnership" to become firmly established in the theory and practice of regulating social and labor relations between employees and employers [9].

The change in the type of social and labor relations in Russia and the social costs of this process have set sociologists, political scientists, philosophers, economists and lawyers the task of scientifically substantiating social partnership as a social phenomenon, explaining its contradictions, outlining development prospects, and analysing forms of regulation. The formal beginning of the approval of social partnership can be considered the creation of the International Labor Organization, which builds its work on the principles of tripartism. In Russia, such a starting point was the Decree of the President of the RSFSR of November 15, 1991, No. 212 "On social partnership and resolution of labor disputes (conflicts)". Later, on its basis, Federal Law No. 92-FZ of May 1, 1999 "On the Russian Tripartite Commission for the Regulation of Social and Labor Relations" was adopted. To coordinate employers' actions in regulating social and labor relations, the Coordinating Council of Employers' Associations of Russia was established in the early 1990s. An essential stage in the information and legal formation of employers' associations as a full-fledged participant in the negotiation process was the adoption of Federal Law No. 156-FZ of November 27, 2002 "On Employers' Associations", which allowed to accelerate the consolidation of business communities. The creation of regional and territorial associations of employers has accelerated social dialogue development at all levels. The specifics of the formation of social partnership relations at the present stage is their formation in the conditions of refusal from the centralisation of labor relations regulation [10]. The weakening of state interference in labor relations significantly increases the role of local regulation, in which contractual forms of establishing the rights and obligations of participants in the labor process are of decisive importance [11].

\section{RESULTS AND DISCUSSIONS}

Social partnership is the category of a mature market economy characterised by social partners' institutionalisation. 
The Labor Code of the Russian Federation of 30.12.2001 N 197-FZ (LC RF) is the first federal law regulating the entire complex of social partnership relations in the Russian Federation. Previously, the existing federal legislation was applied only to certain manifestations of social partnership between employees and employers (the conclusion of collective agreements and agreements and the activities of tripartite commissions on the regulation of social and labor relations).

In foreign countries, the social partnership became widespread at the beginning of the 20th century and is used as a tool for crisis management and socio-economic development. Considering social partnership as a factor of increasing the social policy's effectiveness, it is revealed that this approach contributes to establishing a new discourse in management, the formation of responsible, disciplined partners [12].

The following conditions are necessary to ensure the freedom of association of employees and employers:

1) non-governmental associations of employees and employers are established voluntarily in the form of organisations, and they are managed based on democracy;

2) independence of employee associations and employers' associations from each other, from the state, from any social groups and political parties);

3) the main goal of employee associations is labor protection and improved working conditions and economic conditions [13].

Social partnership in a broad sense is a jointly distributed activity of social elements - representatives of various social groups, the result of which is positive effects accepted by all participants in this activity. Simultaneously, these activities can be carried out permanently and situationally, through specially planned actions within the social partnership framework. Social partnership is a way to build a civil society [14].

Some researchers point out the existence of possible limitations of the social partnership due to the state's authoritarian role, which creates asymmetry in management networks and reduces the quality of interaction between authorities and other subjects of partnership [15].

Russia is developing one of the most complex social partnership systems in the world; it is characterised by a multi-level nature and significant structuring [16].

According to the Labor Code of the Russian Federation, the Russian social partnership system has six levels.

The Russian model of social partnership is based on:
- general laws and general principles of social partnership inherent in this phenomenon, regardless of its belonging to a particular country;

- international legal norms regulating social and labor relations;

- rational use of the world experience of the formation and development of social partnership in Russian practice with mandatory consideration of Russian specifics;

- considering new factors and phenomena that bring domestic experience and modern realities to the practice of social partnership.

Synthesising the above characteristics of social and labor relations, we can conclude that they represent a unique system of relations between different social groups regarding the organisation, regulation of the labor process and the fair division of its results. At the same time, these processes should have a legally supported basis.

Under the influence of these processes, there is a transformation of the sphere of labor, the emergence of qualitatively new trends in its development. Experts of the International Labor Organisation in their report "Working for a better future" highlight the following most important trends:

- the reduction of jobs in traditional sectors of the economy;

- dissemination of new technologies that require retraining and retraining of employees;

- rapid "obsolescence" of professional skills and the need to create a system of "continuous" professional training;

- the growth of unemployment due to demographic changes, the aggravation of the problem of employment and pension provision;

- expansion of informal employment due to the emergence of new forms of labor and entrepreneurial activity [17].

Based on the analysis of various scientists' views and the authors' point of view on the content, subject, sides, goals and final result of the implementation of social and labor relations, we will try to give our definition of this category. In our opinion, social and labor relations should be considered as a historically defined system of relations that arise between employees, employers and the state within the framework of socio-economic relations in the field of labor and related areas of social production, the purpose of which is to balance the interests of the parties and achieve social harmony [18].

The term "social partnership" and the related concepts of "tripartism" and" bipartism" appeared relatively recently, in the 20th century. However, the ideas of 
cooperation, compromise, and harmonisation in relations between different social groups manifested primarily in moral solidarity in society and consensus on social values at the level of politics and ideology, appeared much earlier [19].

In general, it can be noted that the principle of equality of all parties to social and labor relations, as well as maximum consideration of their interests, are the main principles of labor organisation [20].

\section{CONCLUSIONS}

The formation of a system of social partnership in current socio-economic conditions is a rather long and complicated process, depending on several subjective and objective reasons - the state of the economy, the social situation, the willingness of authorities to join it and the will, desire and ability of the heads of organisations.

We share the position that considers social partnership as one of the directions of social and labor policy, and we believe that social partnership is an institutional impact on the formation of labor relations.

Article 27 of the Labor Code of the Russian Federation specifies only some forms of social partnership. The absence in the Labor Code of the Russian Federation of an indication of the possibility of implementing social partnership in other forms than those specified in Article 27 is a significant drawback of Russian labor legislation. It seems appropriate to supplement it with the possibility of participation of employers and their associations, trade unions, and other representative bodies of employees to promote employment, ensure labor protection requirements, and prevent industrial injuries and occupational diseases.

Social partnership is a multifaceted phenomenon. It is also the element of the labor law; the political-legal ideology; the principle of labor law; the way of coordination and promotion of the interests of workers and employers in labor and other directly associated relations; Institute for labor law and also an essential attribute of the modern welfare state. Depending on the social state model, one or another social partnership model is built that meets the specific needs of the state, civil society and the market.

\section{REFERENCES}

[1] L.L. Buntovskikh, D.I. Strelchenko, Problems of State regulation of social and labor relations in Russia, Sustainable Development of Science and education 7 (2019) 40.

[2] Labor Code of the Russian Federation of 30.12.2001 N 197-FZ, Article 23.
[3] The Future of Jobs Report 2018, Centre for the New Economy and Society, World Economic Forum, Geneva, 2018. Retrieved from: http://www3.weforum.org/docs/WEF_Future of J obs_2018.pdf

[4] A.N. Malinkin, Social Partnership in Germany, Domestic notes [Otechestvennye zapiski], Iss. 3, 2003.

[5] V. Guttmann, Industriepolitik I (Theorie), in: Bekerath, E.v. et al. (Hrsg.): Handwörterbuch der Sozialwissenschaften, Bd. 5, Stuttgart u.a.o. 1956.

[6] J. Nelson, S. Zadek, Partnership alchemy, new social partnership in Europe, The Copenhagen Centre \& AccountAbility, Copenhagen, 2003.

[7] G.P. Zinchenko, I.I. Rogov, Social Partnership, Moscow: Academcentre, 2010.

[8] S.P. Peregudov, Tripartite institutions in the West and Russia: Problems of renewal, Polis 3 (2007) 7891.

[9] A.I. Rashidova, Social partnership in the sphere of labor as a category of a mature market economy, Issues of the economy structuring 3 (2012) 225.

[10] A.M. Kurennoy, S.P. Mavrin, E.B. Khokhlov, Comments on the Labor Code of the Russian Federation, 2nd ed., Moscow: Publishing House "Gorodets", 2007.

[11] A.M. Lushnikov, M.V. Lushnikova, Essays on the theory of labor law, St. Petersburg: Law Centre Press, 2006.

[12] R. Kunz, Governing International Migration through Partnership, Third World Quarterly Vol. 34 Iss. 7 (2013) 1227-1246.

[13] J. Kirchner, P.R. Kremp. M. Magotsch, Key Aspects of German Employment and Labor Law, SpringerVerlag Berlin Heidelberg, 2010, 187 p.

[14] A.I. Rashidova, Social Partnership in Professional Education, Universum: Herzen University Bulletin 2 (2012) 31.

[15] K. Johnston, Public governance: the government of non-state actors in partnerships, Public Money \& Management Vol. 35 Iss. 1 (2015) 15-22.

[16] I.S. Bolshukhina, Social partnership as a mechanism for improving the system of social and labor relations, Ulyanovsk, 2010, 183 p.

[17] Work for a better future. Global Commission on the Future of Work, International Labor Organization, International Labor Office, Geneva, 2019, 88 p. Retrieved from: https://www.ilo.org/wcmsp5/groups/public/dgrepor 
ts/cabinet/documents/publication/wcms 662472.pd $\underline{\mathrm{f}}$

[18] I.A. Kondaurova, E.S. Chekh, Features of regulation of social and labor relations, Collection of scientific works of the series "Public Administration" 15 (2019) 245.

[19] N.G. Dekhanova, Social partnership as a mechanism for coordinating group interests, Moscow University Bulletin, Ser. 18. Sociology and Political Science Vol. 24 Iss. 4 (2018) 123.

[20] K.V. Vodenko, Modern Institutes and Regulatory Forms of Social and Labor Relations in Russian Society, International Review of Management and Marketing, 2016, pp. 185-190. 